\title{
First evidence of Mespilus germanica L. (medlar) in Roman Switzerland
}

\author{
Britta Pollmann · Stefanie Jacomet
}

Received: 28 April 2011/Accepted: 20 August 2011/Published online: 3 September 2011

(C) Springer-Verlag 2011

\begin{abstract}
The Mespilus (medlar) fruit tree, non-native in Europe, is generally believed to have been introduced to central Europe during the Roman occupation of the region. Archaeobotanical remains of medlar are generally rare, resulting in a patchy knowledge of its early distribution. We here report the earliest finds of Mespilus seeds of the 2nd century A.D. in Switzerland, which were discovered in the Roman vicus of Tasgetium in Eschenz. We summarize the archaeobotanical evidence of Mespilus fruit stones in central Europe during Roman times, which indicate a wide geographical distribution of Mespilus. In addition, we give an overview of Roman sources about the use of medlar fruit and glance at medieval evidence.
\end{abstract}

Keywords Archaeobotany - Vicus of Tasgetium ·

Lake Constance region · Waterlogged · Historical sources · Fruit cultivation

\section{Introduction}

Mespilus germanica L. (medlar) is a white flowered shrub or small tree of the rose family and related to apples and pears (family: Rosaceae, subfamily: Maloideae, genus: Mespilus) (Schmeil 1996). The green-brown and softly

Communicated by M. van der Veen.

Electronic supplementary material The online version of this article (doi:10.1007/s00334-011-0317-z) contains supplementary material, which is available to authorized users.

B. Pollmann $(\bowtie) \cdot$ S. Jacomet

Institute for Prehistory and Archaeological Science, University

of Basel, Spalenring 145, 4055 Basel, Switzerland

e-mail: britta.pollmann@unibas.ch hairy fruit usually contain five stony seeds (Fig. 1). After the first hard frost, the fruit must be stored in a dry cool place until the flesh, which is initially still hard, green and tart, softens and changes colour to a light brown, a process called bletting. It then becomes suitable for consumption. The pulp then has a distinctive slightly sour flavour and can be consumed directly, processed as a preserve or used for bakery (Baird and Thieret 1989; Knörzer and Gerlach 1999b).

Mespilus originated in southwest Asia (Lauber and Wagner 2001, p. 558; Baird and Thieret 1989, p. 330) or in southeast Europe (Schmeil 1996, p. 247; Lauber and Wagner 2001, p. 558). Although one possible specimen of Mespilus charcoal from the pre-Roman period was found in France (Durand 1991) cited in Ruas and in Marinval (Ruas 1996, Table 4 and footnote 2 on p. 105; Marinval 1999, p. 64), it is generally assumed that Mespilus was first introduced to central Europe by the Romans (Knörzer and Gerlach 1999a, p. 96; Willerding 1996, p. 15; Marinval 1999, p. 50). Archaeobotanical finds of Mespilus seeds occur with the Roman occupation in France, and north of the Alps as in the lower Rhine valley in Germany (Knörzer 1987). In Roman Britain there is evidence of Mespilus in the 2nd century A.D. (Baird and Thieret 1989, p. 346).

In the Middle Ages, both archaeobotanical finds (de Hingh and Bakels 1996; Rippmann and Neumeister-Taroni 2000, pp. 179, 181; Brombacher 1999) and historical sources show the popularity of Mespilus (citations of historical sources in Knörzer and Gerlach 1999b, p. 111; Baird and Thieret 1989, p. 346, Dickson 1994, p. 68; Hellmund 2007, p. 194). It was a common fruit tree in central European gardens for centuries. Today it is rare in central Europe and hence in southern Germany and northern Switzerland (Baird and Thieret 1989, p. 354; Knörzer and Gerlach 1999b, p. 111; Sebald et al. 1992), but 


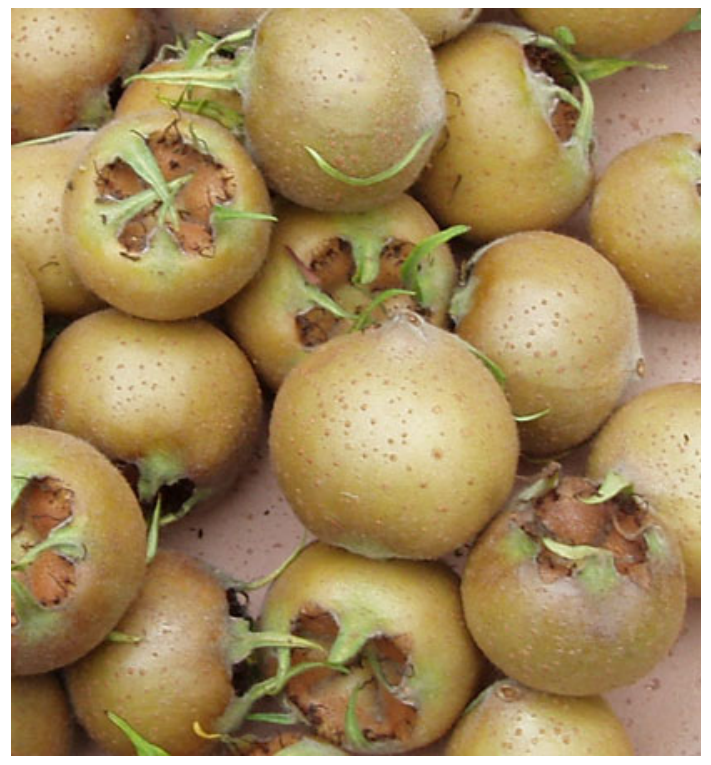

Fig. 1 Modern fruits of Mespilus germanica (medlar), photo by B. Pollmann

one can still find single trees in private orchards, botanical gardens and arboreta (for example, Albisbodenhof Baumschule, northeastern Switzerland), monastery gardens (for example, Kloster Schöntal, southern Germany) or in palace grounds (for example, Schloss Schwetzingen, southern Germany).

So far, little is known about the early distribution of Mespilus in central Europe. As Roman sources are only available for the southern parts of the continent (see discussion), we must rely on archaeobotanical evidence to reconstruct the distribution of Mespilus beyond that area. This paper presents seeds of Mespilus discovered in the Roman vicus of Tasgetium in Eschenz, Switzerland. It represents the earliest evidence of its kind in Switzerland and thus contributes valuable information on the history of Mespilus cultivation in central Europe.

\section{Materials and methods}

The Roman vicus of Tasgetium, now Eschenz, Switzerland, was situated on the south bank of the Rhine where the river leaves Lake Constance (Bodensee) to the west (Fig. 2). The vicus, a small Roman civil settlement, was located on important trade routes that followed and crossed the Rhine at that point. The wooden piles of a bridge found in the river were dated by dendrochronology to the second half of the 1 st to the 3 rd centuries A.D. (Brem 1997). In addition, many of the excavated settlement structures were preserved in a waterlogged state. This allowed a dendrochronological dating of the vicus to between the beginning of the 1 st century and the end of the 3rd century A.D.

Wooden structures like drains, sewers, cesspits and basins contained numerous organic artefacts (Jauch 1997) as well as ecofacts in an excellent waterlogged state of preservation. In excavations carried out during the years 1999 and 2000 (Brem et al. 1999), seeds of Mespilus

Fig. 2 Map of Switzerland with a detailed view of the Lake Constance region showing the locations of the vicus of Tasgetium (Eschenz) and the town of Stein am Rhein, (C) 2007 Bundesamt für Landestopografie

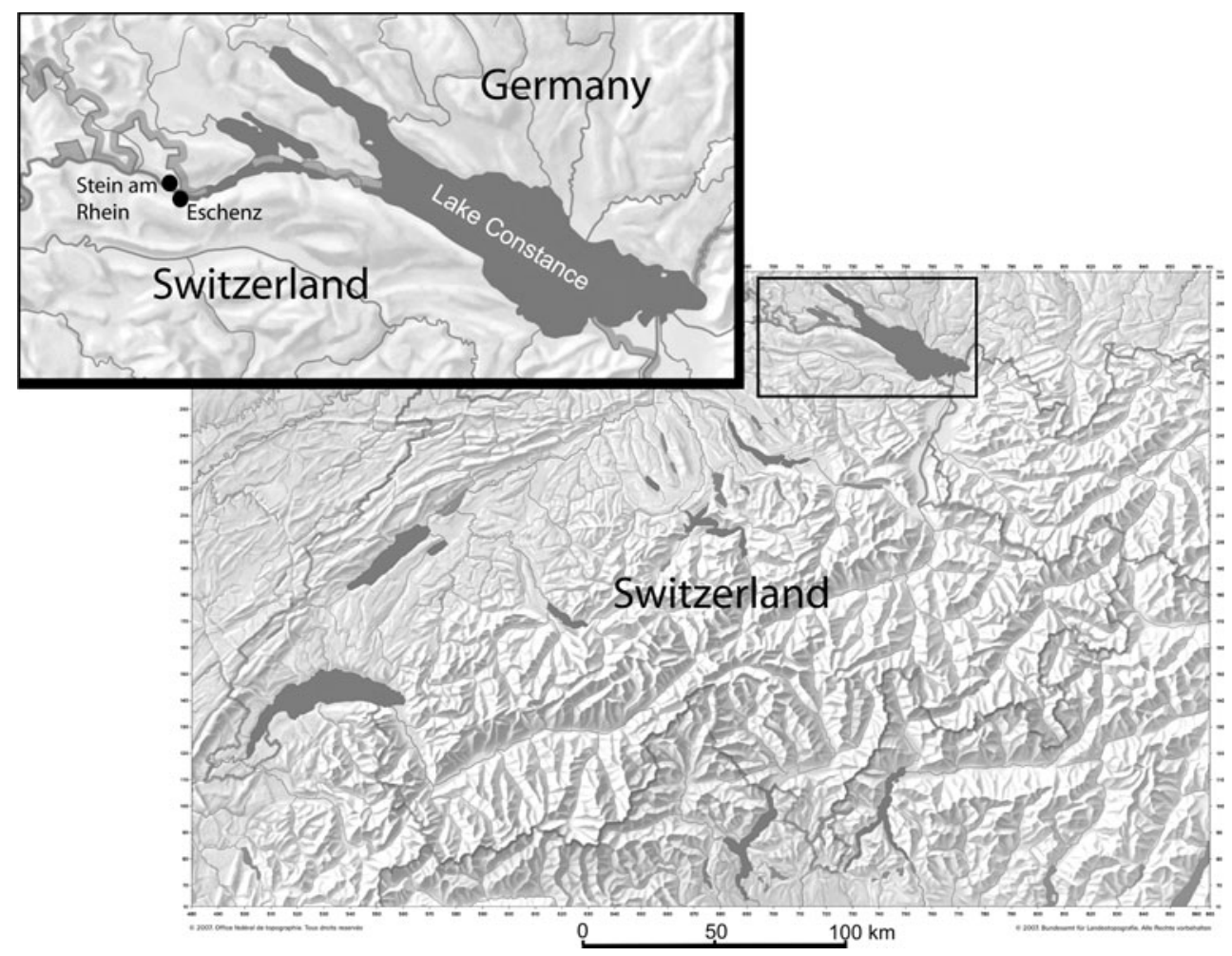


germanica were found in an archaeobotanical sample from a wooden basin containing rubbish and faeces of the Roman inhabitants. The sample was taken close to the stone foundations of a building of as yet undetermined function (ESM Fig. 1). The basin is dated by dendrochronology to the second half of the 1st century A.D., with the most recent contents assigned to the second half of the 2 nd century A.D. or later by numismatics.

Sediment samples from the excavation in Eschenz (excavation number 1999.010) containing plant remains were stored in airtight boxes at temperatures between 10 and $15^{\circ} \mathrm{C}$ for up to 2 years. The archaeobotanical material was extracted using semi-flotation with the wash-over method (Hosch and Zibulski 2003; Tolar et al. 2009). Sieves with mesh sizes of 4,1 and $0.35 \mathrm{~mm}$ were used. In cases where many wood chips were present in the samples, a sieve with a mesh size of $8 \mathrm{~mm}$ was used additionally to separate large objects. After sieving, the 8 and $4 \mathrm{~mm}$ fractions were checked completely. The 1 and $0.35 \mathrm{~mm}$ fractions were randomly subsampled and then analysed under a stereomicroscope with 6 to $40 \times$ magnification. The seeds and fruits were separated and identified with help of the seed reference collection of the Institute for Prehistory and Archaeological Science of the University of Basel as well as special literature for seed and plant identification (Cappers et al. 2006). The Mespilus seeds and seed fragments were found in the 8 and $4 \mathrm{~mm}$ fractions of soil sample no. 33 with an original total volume of $10.5 \mathrm{l}$. Both the $8 \mathrm{~mm}$ fraction $(2 \mathrm{l})$ and the $4 \mathrm{~mm}$ fraction $(1.85 \mathrm{l})$ were checked completely.

\section{Results}

In total, 19 seeds and three seed fragments of Mespilus were identified (Figs. 3, 4). Due to the waterlogged conditions beneath the ground water table, the subfossil seeds are very well preserved. They are brownish to black in colour, in contrast to the characteristic red or orange colour of modern seeds (Fig. 3). In a lateral view, the seeds are almost triangular in shape, sometimes reminiscent of a sector from an irregular disk. The slightly arched dorsal edge is broad and often characterised by a central V-shaped groove (Fig. 3c). The lateral sides show ridges of different thickness. The ventral side is typically characterised by a small ridge. The surfaces of the seeds are irregularly corrugated and hence seem porous. A finely meshed cell structure can be recognized in some areas of the seed surfaces. The measurements of all recovered seeds are listed in Table 1.

Following the criteria of Schibler and Jacomet (1996), the content of the basin is interpreted as representing mainly kitchen waste. Characteristic remains that occur in original latrine contents are a large amount of mineralised aggregations, small seeds of fig and strawberry, deformed and partially digested fish bones. In contrast, bigger fruit stones and nut shells, and other rubbish like broken pots etc. would have been absent or very rare in latrine deposits. The large number of fruit stones of plum, damson, cherry and especially peach, many nut shells (also large parts of walnut shells) and the few mineralised botanical remains, as well as bigger ceramic fragments, suggest that during the final stage the basin was not used exclusively as a latrine but mainly for the deposition of waste.

Beside the Mespilus seeds, remains of numerous wild and cultivated taxa were identified at the site (Table 2). The great majority of the plant remains were preserved waterlogged, with some charred and mineralised specimens among them. Quite remarkable is the large number of fruit stones, which have already been the subject of morphometric and ancient DNA studies (Pollmann et al. 2005).
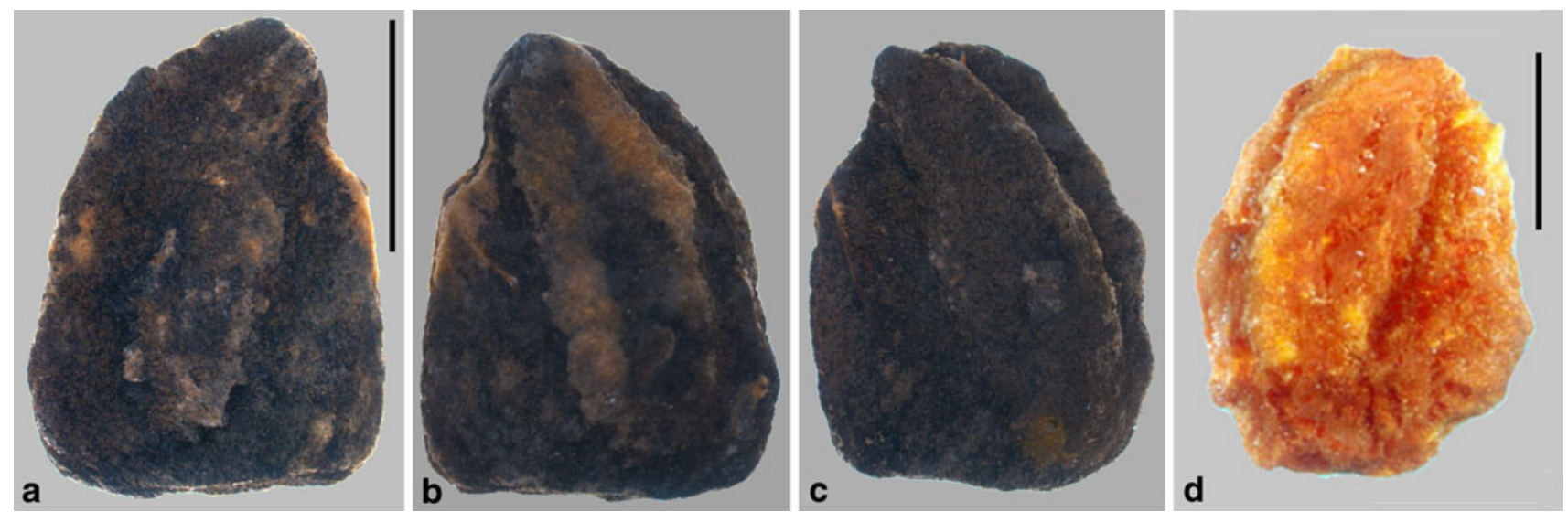

Fig. 3 Waterlogged Roman Mespilus germanica seed from Eschenz (2nd century A.D.); a, b opposite lateral sides of the same seed; $\mathbf{c}$ a second specimen, lateral view; d modern Mespilus seed with characteristic orange to red colour; scale bar $=5 \mathrm{~mm}$; photos by B. Pollmann 


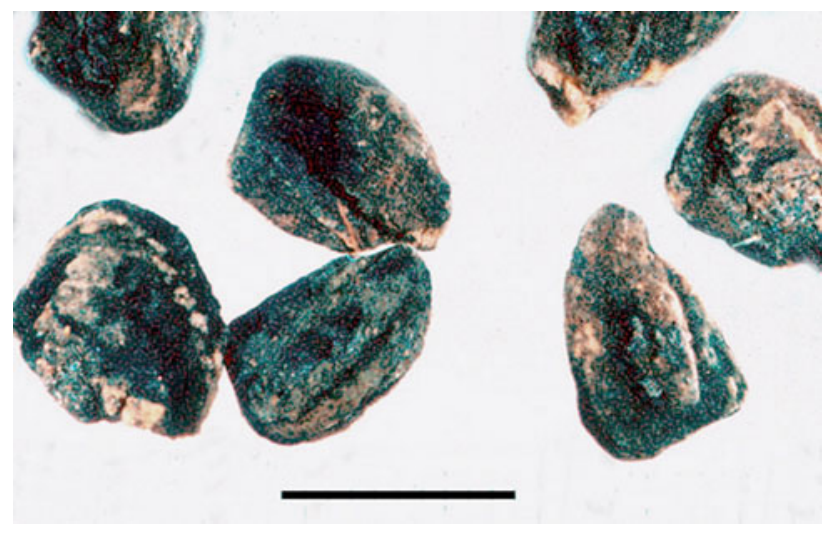

Fig. 4 Assemblage of waterlogged Roman Mespilus seeds from Eschenz (2nd century A.D.), photo by www.archaeologie.tg.ch

Table 1 Dimensions of the Mespilus seeds found at the vicus of Tasgetium, Eschenz, $\mathrm{CH}$

\begin{tabular}{lll}
\hline No. & Length $(\mathrm{mm})$ & Breadth $(\mathrm{mm})$ \\
\hline 1 & 8.2 & 4.8 \\
2 & 9.1 & 7.2 \\
3 & 9.4 & 6.9 \\
4 & 10.2 & 6.8 \\
5 & 9 & 7 \\
6 & 8.9 & 6.6 \\
7 & 10 & 7.1 \\
8 & 9.8 & 8 \\
9 & 11.4 & 6.5 \\
10 & 10.2 & 7.5 \\
11 & 9.6 & 6.9 \\
12 & 8.5 & 6.5 \\
13 & 10.3 & 7.8 \\
14 & 10 & 9 \\
15 & 10 & 7 \\
16 & 10 & 7.6 \\
17 & 10 & 7.8 \\
18 & 9.6 & 7 \\
19 & 10.5 & 6.8 \\
Mean & 9.7 & 7.1 \\
Median & 10.0 & 7.0 \\
S.D. & 0.8 & 0.8 \\
\hline
\end{tabular}

\section{Discussion}

In general, finds of Mespilus are rare in Roman contexts in central and western Europe (Table 3). Mespilus occurs in various archaeological contexts; it was found in a funerary context in France, outside the Roman city walls of Colonia Claudia Ara Agrippinensium, and in an urban context in Troyes and Reims in France and in smaller civil
Table 2 List of cultivated food plants and probably collected wild fruits that were found in Eschenz/Tasgetium (Pollmann 2003; Feigenwinter 1997)

Cereals

Avena sp. (grain)

Hordeum vulgare L. (grain)

Panicum miliaceum L. (grain, chaff)

Triticum dicoccon Schr. (chaff)

Triticum monococcon L. (chaff)

Triticum spelta L. (grain, chaff)

Cerealia (grain)

Pulses

Lens culinaris Med.

cf Pisum sativum L.

Vicia faba L.

Fruits and nuts

Corylus avellana $\mathrm{L}$.

Oat (grass)

Cucumis sativus $\mathrm{L}$.

Barley

Cucumis cf melo L.

Ficus carica L.

Fragaria vesca $\mathrm{L}$.

Broomcorn millet

Juglans regia L.

Emmer

Einkorn

Spelt

Cereals

Juniperus communis L.

Malus/Pyrus

Mespilus germanica L.

Lentil

Probably pea

Broad bean

Hazelnut

Cucumber

Probably melon

Fig

Strawberry

Walnut

Common juniper

Apple/pear

Medlar

Prunus avium L., P. avium/cerasus

Cherry

Prunus domestica $\mathrm{L}$.

Plum

Prunus insititia L.

Damson

Prunus persica (L.) Batsch

Peach

Prunus spinosa $\mathrm{L}$.

Sloe

Pyrus communis L. em. Gaertn.

Pear

Rosa sp.

Rose/rose hip

Rubus fruticosus L.

Blackberry

Rubus idaeus L.

Raspberry

Sambucus nigra/racemosa

Elder

Vitis vinifera $\mathrm{L}$.

Vine grape

Other cultivated plants

Anethum graveolens L. Dill

Apium graveolens L. Celery

Beta vulgaris $\mathrm{L}$. Beet

Brassica sp.

Coriandrum sativum $\mathrm{L}$.

Cabbage spp.

Coriander

Linum usitatissimum $\mathrm{L}$.

Flax

Papaver somniferum $\mathrm{L}$.

Opium poppy

Satureja hortensis L.

Summer savory

settlements as in the vicus of Nidderau-Heldenbergen or in the rural site at Novy-Chevrières. They show that the fruits were used not only in the Mediterranean parts of the Roman Empire, as known from written sources, but also in 


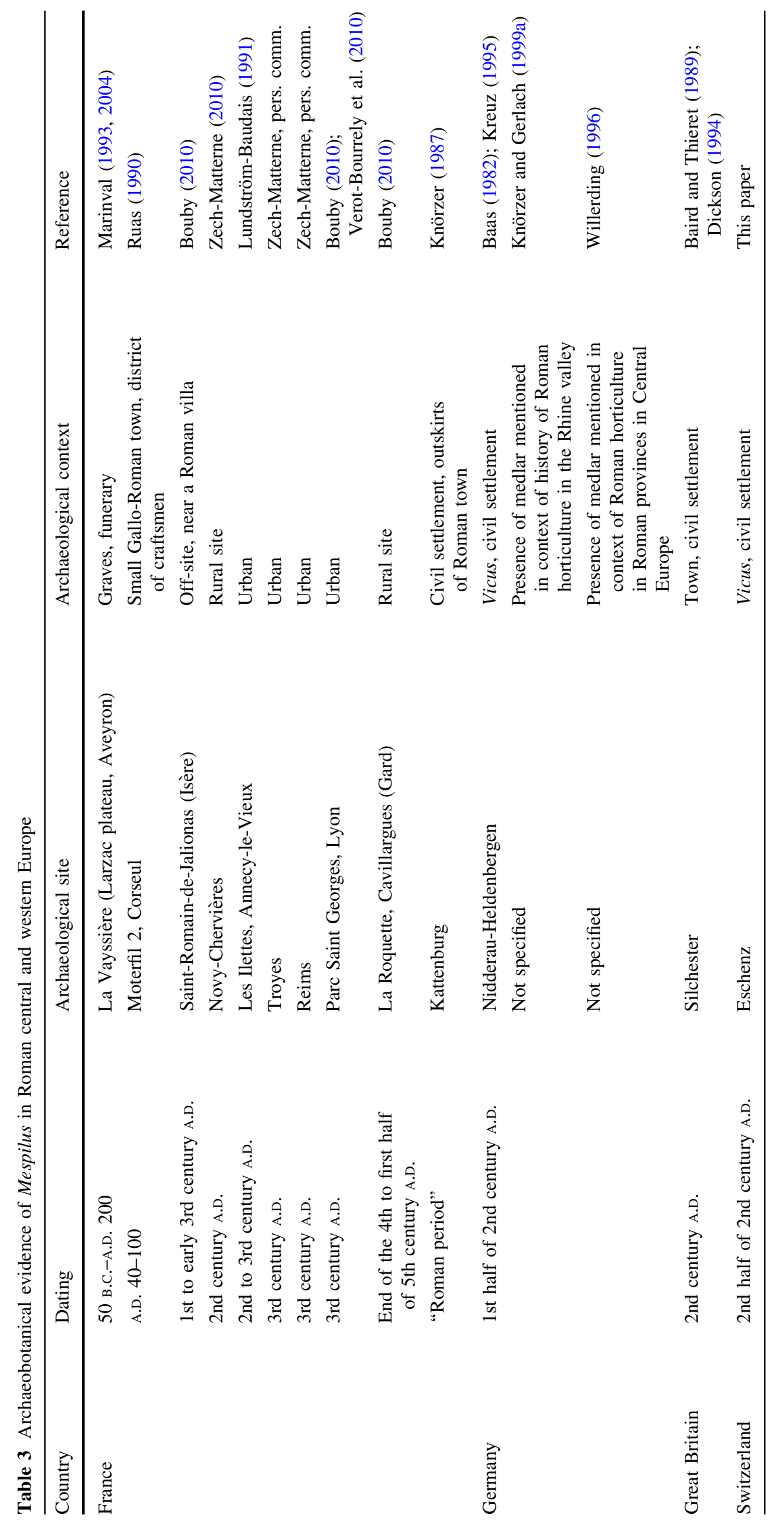


the northern provinces. Now the finds in Eschenz also establish the use of Mespilus in Roman Switzerland.

To increase our knowledge about the processing, use and importance of Mespilus in Roman times we can use both the archaeobotanical information and the historical sources in which Roman customs and uses of Mespilus are reported for southern Europe. Since carbonised Mespilus seeds as well as remains of apples, dates, olives etc. are found in Roman cremation burials, it is assumed that the fruit held some cultural meaning connected with fertility, life after death and immortality (Ruas 1996, p. 99). In contrast, the finds in Eschenz suggest a use in the kitchen because they were found mixed with other discarded fruit remains. However, the occurrence of Mespilus in kitchen waste does not permit us to safely conclude what it was used for. It is most likely that it was used for consumption, but a medical application can also not be excluded.

Historical sources contain various pieces of information on the use of mespilus in ancient times. In antiquity, three types of mespilus were known, all of them mentioned by Pliny the Elder (Pliny, nat. hist. 15, 84): the anthedonian mespilus ("mespilus anthedon") (Ovid, M VII 232), the setanian mespilus (" $\mu \varepsilon \varsigma \pi l \lambda \eta \quad \sigma \eta \tau \alpha \nu l o \varsigma$ ") (Theophrastus, III, 12, 5), and the Gallic mespilus ("Gallicus vocant", Pliny, nat. hist. 15, 84). Various authors such as Pliny the Elder, Palladius and Dioscorides describe the appearance and characteristics of mespilus (Magerstedt 1861). However, just one of these seems to be identical to modern Mespilus germanica L. Starting with the description of mespilus cultivation by Palladius we may assume that the fruit called mespilus in Roman texts is identical with the botanical M. germanica L. (André 1998) from the 5th century A.D. onwards. Pliny the Elder states that mespilus was not cultivated in Italy in the times of Cato (2nd century в.C.) (Pliny, nat. hist. 15, 84). Columella, a Roman author of the 1st century A.D., did not mention mespilus in his work Liber de arboribus (Baird and Thieret 1989), where he provides plentiful information about other fruit trees. Neither did Apicius recommend recipes for the consumption of mespilus (Maier 1991).

Other written sources do however provide information about the use of mespilus in the 1st century A.D. in the Mediterranean. For instance Palladius writes that the fruits of mespilus were preserved in honey since the 1st century A.D. (Pall. agric. 4, 10, 22). Dioscorides (1st century A.D.) mentions the astringent effect of mespilus, which can cause constipation (Diosc. I 170). In the 2nd century A.D. the prominent Roman physician Galen reported on different uses of mespilus against somatic discomfort and pain (Grant 2000). This latter historical source is more or less contemporary with the finds in Eschenz.

Beside its use, there is the question whether medlar was grown locally or imported when finds occur in Roman contexts. In the case of Mespilus in Eschenz, at the end of the 2nd century A.D., both scenarios are possible. The reported status of horticulture in the Rhine valley by Pliny the Elder makes it likely that Mespilus could also have been locally cultivated. From Pliny the Elder we know that cherries were grown by the river Rhine (Pliny, nat. hist. 15, 103). Local horticulture north of the Alps must also be assumed for various fruit trees like apple, pear and plum in the 2 nd century A.D., because the huge amounts of archaeobotanical evidence suggest local cultivation rather than just the import of fruits (Jacomet et al. 2006). Since Mespilus grows very well in regions north of the Alps and a three year old tree already produces a good yield, it is probable that medlar was cultivated locally. Kreuz (1995, p. 70) also assumes that Mespilus was a locally cultivated fruit like 14 other fruit taxa in Roman gardens in the Hessen region, Germany. In contrast, other fruits that were found in Eschenz were imports, such as figs, and we cannot exclude that Mespilus was also imported to the vicus of Tasgetium. This is especially since we have found Mespilus seeds in just one single sediment sample up to now, but it has not been found all over the settlement in different archaeobotanical samples. For final proof, wood of Mespilus needs to be found in situ. Pollen evidence is usually a good indicator for local cultivation, too. In the case of Mespilus, however, the pollen cannot be identified to the species level (Beug 2004).

In contrast to the Roman period, the finds of Mespilus are quite frequent in the following centuries. The popularity of medlar in the centuries following antiquity is verifiable by written sources and many medieval and modern finds of $M$. germanica seeds. Just a few examples of finds from the 7th century onwards give an impression that Mespilus was a favourite fruit plant in these times (De Hingh and Bakels 1996; Brombacher 1999; Rippmann and Neumeister-Taroni 2000, pp. 179, 181; Dickson 1994; Kučan 1998, p. 251; Brinkkemper and Vermeeren 1998; Karg 2008; Knörzer and Gerlach 1999b; Troubleyn et al. 2009). In addition to written sources, images on paintings or textiles may indicate the use of Mespilus fruit or plants, thus Mespilus is shown on a tapestry of the 16th century A.D. (Baird and Thieret 1989, p. 350).

Interestingly, from a regional perspective, fruit stones of Mespilus were found in a cesspit in Stein am Rhein, a small town about $1.5 \mathrm{~km}$ to the west of the Roman vicus of Tasgetium dating to about A.D. 1300 (Fig. 2; Brombacher and Klee 2006, p. 159). The question is whether there was a continuity of Mespilus cultivation in the mild climate of Lake Constance and the Rhine valley from Roman to medieval and early modern times. This is of special interest because even today the region of Lake Constance is well known for its fruit cultivation, especially for apples (Hammerl et al. 2005, p. 30; www.fructus.ch). The hypothesis of this tradition going back 
to Roman times needs to be verified by further archaeobotanical work and a survey of the recent distribution of Mespilus in the region of Lake Constance.

Acknowledgments We would like to thank Hansjörg Brem and his colleagues of the Amt für Archäologie of Canton Thurgau $(\mathrm{CH})$ for providing the plant material from the Eschenz 1999.010 excavation for archaeobotanical analyses and for their good collaboration. Our colleagues of the IPAS archaeobotanical group and the reviewers we thank for valuable discussions and helpful comments and Sandra Pichler for revision of the English text.

\section{References}

André J (1998) Essen und Trinken im alten Rom. Reclam, Stuttgart Baas J (1982) Kultur- und Nutzpflanzen aus römischen Siedlungsgruben in Nidderau-Heldenbergen (Mainz-Kinzig-Kreis). Saalbg Jahrb 38:110-119

Baird JR, Thieret JW (1989) The medlar (Mespilus germanica, Rosaceae) from antiquity to obscurity. Econ Bot 43:328-372

Beug H-J (2004) Leitfaden der Pollenbestimmung für Mitteleuropa und angrenzende Gebiete. Pfeil, München

Bouby L (2010) Agriculture dans le bassin du Rhône, du Bronze final à l'Antiquité. Agrobiodiversité, économie, cultures. EHESS, Dissertation, University of Toulouse le Mirail

Brem H (1997) Leben mit der Grenze: die römische Zeit im Thurgau. Archäol Schweiz 20:80-83

Brem H, Steiner D, Kesselring R (1999) Neues aus Tasgetium. Archäol Schweiz 22:123-134

Brinkkemper O, Vermeeren C (1998) Mediterrane rijst en oosterse kruidnagels. Botanisch onderzoek van twee beermonsters. [Mediterranean rice and oriental cloves. Archaeobotanical research of two cesspit samples]. In: Barwasser M, Smit M (eds) Acht eeuwen tussen twee stegen. Archeologisch, historisch en bouwhistorisch onderzoek in Kampen. Stichting Archeologie IJssel/Vechtstreek, Kampen, pp 145-153

Brombacher C (1999) Die Pflanzenfunde aus den Latrinen. In: Bänteli K, Gamper R, Lehmann P (eds) Das Kloster Allerheiligen in Schaffhausen. Zum 950. Jahr seiner Gründung am 22. November 1049. (Schaffhauser Archäologie 4) Baudepartement des Kantons Schaffhausen. Kantonsarchäologie, Schaffhausen, pp 221-228

Brombacher C, Klee M (2006) Archäobotanische Reste. In: Bänteli K (ed) Das Bürgerasyl in Stein am Rhein-Geschichte eines mittelalterlichen Spitals. (Schaffhauser Archäologie 7) Baudepartement des Kantons Schaffhausen. Kantonsarchäologie, Schaffhausen, pp 151-161

Cappers R, Bekker RM, Jans JEA (2006) Digitale Zadenatlas van Nederland (Digital seed atlas of the Netherlands), (Groningen Archaeological Studies 4) Barkhuis Publishing \& Groningen University Library, Groningen

De Hingh AE, Bakels CC (1996) Palaeobotanical evidence for social difference? The example of the early medieval domain of SerrisLes Ruelles, France. Veget Hist Archaeobot 5:117-120

Dickson C (1994) Macroscopic fossils of garden plants from British Roman and Medieval deposits. In: Moe D, Dickson JH, Jorgensen PM (eds) Garden history: Garden plants, species, forms and varieties from Pompeii to 1800 . Symposium held at the European University Centre for Cultural Heritage, Ravello, June 1991, vol. PACT 42:47-72

Durand A (1991) Paysages, terroirs et peuplement dans les campagnes du Bas-Languedoc (Xe-XIIe siècle). Université de Paris I Panthéon-Sorbonne, Paris
Feigenwinter F (1997) Die Pflanzenfunde aus der Latrine. In: Jauch V (ed) Eschenz-Tasgetium. Römische Abwasserkanäle und Latrinen. (Archäologie im Thurgau 5) Amt für Archäologie des Kantons Thurgau, Frauenfeld, pp 21-28

Grant M (2000) Galen on food and diet. Routledge, London

Hammerl M, Jacoby H, Naumann S, Paas D, Trötschler P (2005) Pro UNESCO-Kulturlandschaft Bodensee, Ein gemeinsames Impulspapier. Bodensee-Stiftung \& Umweltrat Bodensee, Radolfzell

Hellmund M (2007) Pflanzenfunde aus der "Luthergrube". In: Meller H, Schlenker B (eds) Luther in Mansfeld-Forschungen am Elternhaus des Reformators. (Archäologie in Sachsen-Anhalt 6, Sonderband) Landesamt für Denkmalpflege und Archäologie Sachsen-Anhalt, Halle, pp 189-202

Hosch S, Zibulski P (2003) The influence of inconsistent wet-sieving procedures on the macroremains concentration in waterlogged sediments. J Archaeol Sci 30:849-857

Jacomet S, Petrucci-Bavaud M, Kühn M (2006) Samen und Früchte. In: Schucany C (ed) Die römische Villa von Biberist-Spitalhof/SO (Grabungen 1982, 1983, 1986-1989). (Untersuchungen im Wirtschaftsteil und Überlegungen zum Umland, Ausgrabungen und Forschungen 4) BAG Verlag, Solothurn, pp 579-624/877-916

Jauch V (1997) Eschenz-Tasgetium. Römische Abwasserkanäle und Latrinen. (Archäologie im Thurgau 5) Amt für Archäologie des Kantons Thurgau, Frauenfeld

Karg S (2008) Diversität der Nutzpflanzen im Mittelalter Nordeuropas. Archäologische Informationen 31:97-102

Knörzer K-H (1987) Geschichte der synanthropen Vegetation von Köln. Kölner Jahrb für Vor-und Frühgesch 20:271-388

Knörzer K-H, Gerlach R (1999a) Der Wandel der Landwirtschaft unter dem Einfluss Roms. In: Knörzer K-H, Gerlach R, MeurersBalke J et al (eds) PflanzenSpuren. Archäobotanik im Rheinland: Agrarlandschaft und Nutzpflanzen im Wandel der Zeiten. (Materialien zur Bodendenkmalpflege im Rheinland 10) Rheinland Verlag, Köln, pp 93-103

Knörzer K-H, Gerlach R (1999b) Die Blüte der mittelalterlichen Landwirtschaft. In: Knörzer K-H, Gerlach R, Meurers-Balke J, Kalis AJ, Tegtmeier U, Becker WD, Jürgens A (eds) PflanzenSpuren. Archäobotanik im Rheinland: Agrarlandschaft und Nutzpflanzen im Wandel der Zeiten. (Materialien zur Bodendenkmalpflege im Rheinland 10) Rheinland Verlag, Köln, pp 109-118

Kreuz A (1995) Landwirtschaft und ihre ökologischen Grundlagen in den Jahrhunderten um Christi Geburt: zum Stand der naturwissenschaftlichen Untersuchungen in Hessen. Berichte der Kommission für Archäologische Landesforschung in Hessen 3(1994/ 1995):59-91

Kučan D (1998) Zur Ernährungsgeschichte des Spätmittelalters und der frühen Neuzeit in Oldenburg anhand der botanischen Untersuchungen der Altstadtgrabungen. Probleme der Küstenforschung im südlichen Nordseegebiet 25:243-279

Lauber K, Wagner G (2001) Flora Helvetica, 3rd edn. Haupt, Bern

Lundström-Baudais K (1991) Les macrorestes végétaux de deux puits des IIe-IIIe siècle à Annecy-le-Vieux, Les Ilettes. In: Vivian R (ed) Paléoenvironnement Holocène et Archéologie dans les Alpes du Nord et leur piémont. Comité des Travaux Historiques et Scientifiques, Paris, pp 109-113

Magerstedt AF (1861) Die Mispel. In: Magerstedt AF (ed) Bilder aus der römischen Landwirtschaft. Für Archäologen und wissenschaftlich gebildete Landwirte nach den Quellen bearbeitet, vol 4. Die Obstbaumzucht der Römer. Saendig Reprint Verlag, Hans R. Wohlwend, Vaduz (Reprint von: Sonderhausen 1861), pp 160-161

Maier R (ed) (1991) Das römische Kochbuch des Apicius-vollständige zweisprachige Ausgabe. Reclam, Stuttgart

Marinval P (1993) Etude carpologique d'offrandes alimentaires végétales dans les sépultures gallo-romaines: réflexions préliminaires. In: Monde des morts, monde des vivants en Gaule rurale. 
Actes du Colloque ARCHAEA/AGER (Orléans, 7-9. fèvr. 1992). Orléans, pp 45-65

Marinval P (1999) Les fruits et leurs usages au travers des restes archéologiques: en France, de la Préhistoire à l'Antiquité. In: Chauvet M (ed) Le patrimoine fruitier. Hier, aujoud'hui, demain. Actes de colloque de La Ferté Bernard (Sarthe), 16-17 octobre 1998. AFCEV, Paris, pp 53-64

Marinval P (2004) Offrandes alimentaires d'origine végétale en contexte funéraire gallo-romain. In: Baray L (ed) Archéologie des pratiques funeraires. Approches critiques. (Collection Bibracte 9) Centre archéologique européen, Glux-en-Glenne, pp 197-206

Pollmann B (2003) Archäobotanische Makrorestanalysen und molekulararchäologische Untersuchungen an botanischen Funden aus dem römischen vicus Tasgetium (Eschenz/Kanton Thurgau/CH). Universität Basel, Diplomarbeit

Pollmann B, Jacomet S, Schlumbaum A (2005) Morphological and genetic studies of waterlogged Prunus species from the Roman vicus Tasgetium (Eschenz, Switzerland). J Archaeol Sci $32: 1,471-1,480$

Rippmann D, Neumeister-Taroni B (eds) (2000) Gesellschaft und Ernährung um 1000. Eine Archäologie des Essens. Alimentarium, Vevey

Ruas M-P (1990) Recherches carpologiques dans le Massif armoricain du Mésolithique au bas Moyen Age. Mémoire de DEA, EHESS, Paris

Ruas M-P (1996) Eléments pour une histoire de la fructiculture en France: données archéobotaniques de l'antiquité au XVIIe siècle. In: Colardelle M (ed) L'homme et la nature au Moyen Age. Actes du Ve congrès international d'archéologie médiévale (Grenoble). Errance, Paris, pp 92-105
Schibler J, Jacomet S (1996) Pflanzenreste und Tierknochen aus Latrinengruben: Fäkalienreste, Küchen- und Speiseabfälle oder Abraum? In: Historisches Museum Basel (ed) Fundgruben - Stille Örtchen ausgeschöpft. Historisches Museum Basel, Basel, pp 75-76

Schmeil O (1996) Schmeil-Fitschen: Flora von Deutschland und angrenzender Länder. Quelle \& Meyer, Wiesbaden

Sebald O, Seybold S, Philippi G (1992) Die Farn- und Blütenpflanzen Baden-Württembergs vol 3. Ulmer, Stuttgart

Tolar T, Jacomet S, Velušček A, Cufar K (2009) Recovery techniques for waterlogged archaeological sediments: a comparison of different treatment methods for samples from Neolithic lake shore settlements. Veget Hist Archaeobot 19:53-67

Troubleyn L, Kinnaer F, Ervynck A, Beeckmans L, Caluwé D, Cooremans B, De Buyser F, Deforce K, Desender K, Lentacker A, Moens J, Van Bulck G, Van Dijck M, Van Neer W, Wouters W (2009) Consumption patterns and living conditions inside Het Steen, the late medieval prison of Malines (Mechelen, Belgium). J Archaeol Low Ctries 1-2:5-47

Verot-Bourrely A, Argant J, Bouby L, Latour-Argant C, Martin S (2010) Evolution d'un paysage de confluences de la Protohistoire à l'époque gallo-romaine: géomorphologie et paléoenvironnement du site Parc Saint-Georges à Lyon (69-France). Quaternaire 21:413-423

Willerding U (1996) Zur Agrarproduktion von der jüngeren vorrömischen Eisenzeit bis ins frühe Mittelalter. Historicum, LinzPuchenau, pp 10-20

Zech-Matterne V (2010) Le développement de la fructiculture en Gaule du Nord, à l'époque romaine. In: Ouzoulias P, Tranoy L (eds) Comment les Gaules devinrent romaines, Actes du colloque international, September 2007. La Découverte, Paris, pp 255-266 